\title{
The Development of Magnetic Induction Practicum Tool on Solenoid in Exploring the Understanding of Concept at Senior High School Students
}

\author{
Nurmala \\ Postgraduatedof Physics Education \\ State University of Medan \\ MTsN 3 Deli Serdang \\ Medan, Indonesia \\ malayamakasi83@gmail.com
}

KaryaSinulingga

Post graduated Lecture of Physics Education

State University of Medan

Medan, Indonesia

\author{
Wawan Bunawan \\ Post graduated Lecture of Physics Education \\ State University of Medan \\ Medan, Indonesia \\ wanbunawan@gmail.com \\ Rahmatsyah \\ Post graduated Lecture of Physics Education \\ State University of Medan \\ Medan, Indonesia
}

\begin{abstract}
The purpose of this study is to know about the eligibility and effectivity of magnetic induction practicum tool on solenoid which was accompanied by student's worksheet (LKPD) to explore students conceptual understanding. The method used in this study was ADDIE Developmet Model. Before it used for more, the practicum tool and LKPD must be testedthe feasibility by seven professional Physics teachers as the validator. The student's responses were also used to see the feasibility for the practicum tool after the practicum process to be held. Based on result of this study showed that the feasibility for the practicum tool tested by validators got 1.00 and the practicum tool has proper specification to determine the magnetic field on the solenoid. In the form of variation of resemble of turns, current and the length of solenoid. The score of students worksheet got 1.00 , so it can conclude that the electromagnetic induction practicum tool on solenoid and students worksheet were in very feasible criteria. The students responses were 0.88 it also very feasible. Gain test result showed that there an increased understanding of students concept after learning using magnetic induction practicum tools of 0.45 and in mastery got $70 \%$. It means in each criteria were at medium. It show that magnetic induction practicum on solenoid can increase the exploring of students conceptual understanding.
\end{abstract}

Keywords: practicum tool, conceptual understanding

\section{INTRODUCTION}

Physics is a part of science, in learning of physics certainly cannot be separated from practicum activities. Practicum is a series of activities to prove the theory and the development of concepts that have been studied. In fact, in learning Physics at school tends to the teacher centered and text book oriented without involving the students in learning activities. At the end the students become uninterested in learning Physics and they have assumption that Physics is difficult to understand and boring.[1]
In learning process at school, it should be emphasized in the discovery process, so that a fun learning process can be created.[2] As a teacher, skills are needed that bridge the delivery of the material of a lesson effectively and efficiently. [3] In learning Physics, it will be more meaningful if the students are actively involved in learning such as observing, understanding, exploring and doing some experiments, so that thinking activities are more honed. There is one way in order the students can be creative with doing the practicum. The implementation of the practicum activities in the class there are still many troubles. The survey result showed that the laboratory facilities at Junior High School and Senior High School in the remote area or in the small island are of Indonesia according to Burhan (1) the facilities, tools and the materials are so limit when compared to the ratio of the number of users, (2) The planned practicum is often delayed because some of the available materials and tools are not in accordance with the needs of the practicum activity and (3) the used of tools and materials just as demonstration method or just for demonstrate some topics.[4]

Deacon stated that "the availability of tools can influence the process of learning at laboratory" [5]. Borroman (2008: 18) argued that "laboratory based-learning can improve the understanding of learning by the students"[6]. One of the materials is related to electricity and magnetism is magnetic induction of a solenoid. At school, tools and the experiment which related to magnetic induction of solenoids are very rarely done because of the limitations of tools. Therefore can make the students uninterested in learning Physics and it will make the students hard to understand the concept of Physics. 
Based on the previous research which have done at SMA N 1 Hamparan Perak and in the other private of Senior High Schools, magnetic induction practicum tools on solenoids do not yet exist. While from the observation in some sellers of the practicum tools based on PUDAK standards, found that there are still tools has deficiency such as; (1)the tool is not economical, because the source of the tool comes from battery or power supply which is so expensive, (2) there is no variation of measurement, resemble of turns, current and the length of solenoid, (3) measuring of the current hard to do, (4) it is not efficient, because the teacher and the students should string up the tools before the practicum starts.

From the explanation above it needs to develop of the magnetic induction practicum tools on solenoids in order the learning process more active, fun and at the end it can explore the students conceptual understanding to the magnetic induction material.

\section{RESEARCH METHOD}

This research is Development Research model. According to Borg and Gall developmental research is a process was used to develop and validity of educational product [7]. This research used ADDIE research model with several steps; Analysis, Design, Development, Implementation and Evaluation. To make a product used ADDIE process is effectively reason because ADDIE is a process that has a function as a framework to a complex situation and it can develop educational product and other source study [8]. Practicum tool which has been develop and accompanied by LKDP (Lembar Kerja Peserta Didik/students work sheet). The research was done at Hamparan Perak Senior High School State 1 (SMA Negeri 1 Hamparan Perak) in April 2018. The population of this research was 144 student of science class level XII, the sample was taken was science class level XII. Sample technique that used was purposive random sampling which is the determination of subject based on the research objectives [9].

Instrument of this research are questionnaire form and essay test. The instrument were develop to measure and evaluate the readability of practicum toll and students worksheet and would be validated by seven Physics' teachers and questionnaire response of students after they used the practicum tool. Essay test used to know about students conceptual understanding. Validity analysis of feasibility of practicum tools, students 'work sheet, and students' responses was analyzed by Content Validity Ratio (CVR). The way to do the calculate of CVR is used the equation [10].

$$
C V R=\left(\frac{2 n_{e}}{n}\right)-1
$$

After every questionnaires items was identified used CVR, next step to calculate the validity index of practicum tool, students' work sheet was used CVI. CVI is the average from CVR point from all validation questionnaire items [10].

$$
C V I=\frac{\text { numberofCVR }}{\text { numberofquestionnaires }}
$$

The criteria of CVR and CVI can be seen at table 1 .

TABLE. 1 THE ASSESSMENT CRITERIA OF CVR AND CVI
\begin{tabular}{|l|l|l|}
\hline No & Score & Validity \\
\hline 1 & $0-0,33$ & Not relevant \\
\hline 2 & $0,34-0,67$ & Relevant \\
\hline 3 & $0,68-1,00$ & Very relevant \\
\hline
\end{tabular}

\section{RESULT AND DISCUSSION}

\section{Practicum Tool Circuit}

In making this magnetic induction practicum tool on the solenoid accompanied with students' work sheet that refers to Main Competence (KI), Basic Competence (KD) and the Purpose of the study in 2013 Curriculum. The circuit of magnetic induction practicum tool on solenoid was made and showed at figure 1.

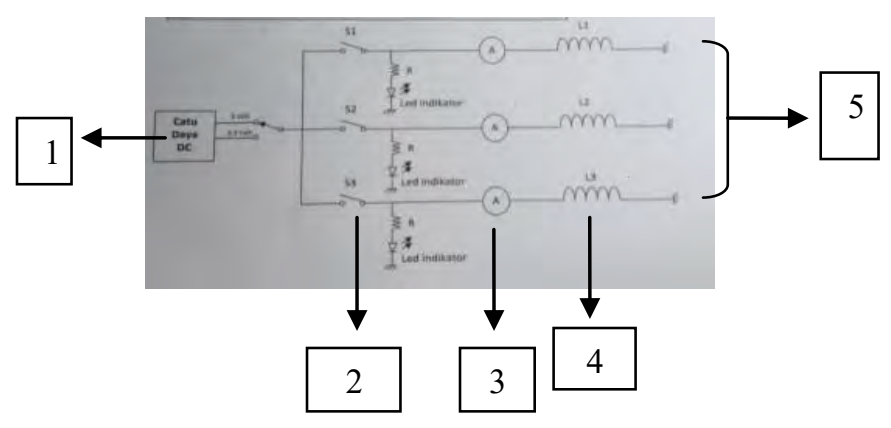

Fig. 1.The Circuit of Magnetic Induction Practicum Tool on Solenoid

The specification from practicum tool has some parts (1) power supply to change from AC become DC, the power supply was from Computer Processor Unit was not used anymore. The power supply will also be varied with the current entering the circuit which is $0.30 \mathrm{~A}, 0.52 \mathrm{~A}, 0.81 \mathrm{~A}$ and $1.20 \mathrm{~A}$. (2) switch as a circuit breaker. (3) Ampere meter as a current measuring device that enters the circuit. (4) Solenoid coils that can be removed and will be varied based on the number of turns $250,500,750$ and 1000 of coils the length of coil there are $1.2 \mathrm{~cm}, 2.3 \mathrm{~cm}, 3.5 \mathrm{~cm}, 4.6 \mathrm{~cm}$ (5) Nail to see the magnitude of magnetic induction on solenoids by weighing the mass of iron powder attached to nails.

\section{The Way to Use the Practicum Tool}

Magnetic induction tool on solenoid works and look likes iron and metal lifting equipment at harbor. If the power supply at the first part (1) connected to a voltage source originating from electrical networks, then the nails (5) placed on the coil (4) will produce magnetic induction. Then the nail will be 
brought close to the iron powder and it will stick. To see the magnitude of magnetic induction is to weigh the mass of iron powder attached to the tip of the nail with a digital scale. Te mass of iron powder is an indicator of the magnitude of magnetic induction on the solenoid. When the practicum tool works, the assembly can measure the current entering the coil (3). This practicum is influenced by 3 variables such as; resemble of coils, current and the length of solenoid.

The Validation of Practicum Tool, Students' Work Sheet and Students' Responses.

Practicum tool validation process is carried out by 7 professional physics teachers and 7 aspects of assessment criteria there are; (I) linkage with teaching material (II) the value of education (III) tool durability (IV) efficiency (V) security for students (VII) esthetics. Assessment is done twice because in the first assessment the practicum tool still has a revision so that the tool must be repaired so that it can be used in the learning process. Validation result at the first assessment is 0.83 with the criteria is very relevant but needed revision. At the second validation the assessment is 1.00 with the criteria is very relevant to become a school practicum tool. Validation result at the first and second time to practicum tool can be seen at the figure 2 and 3 .

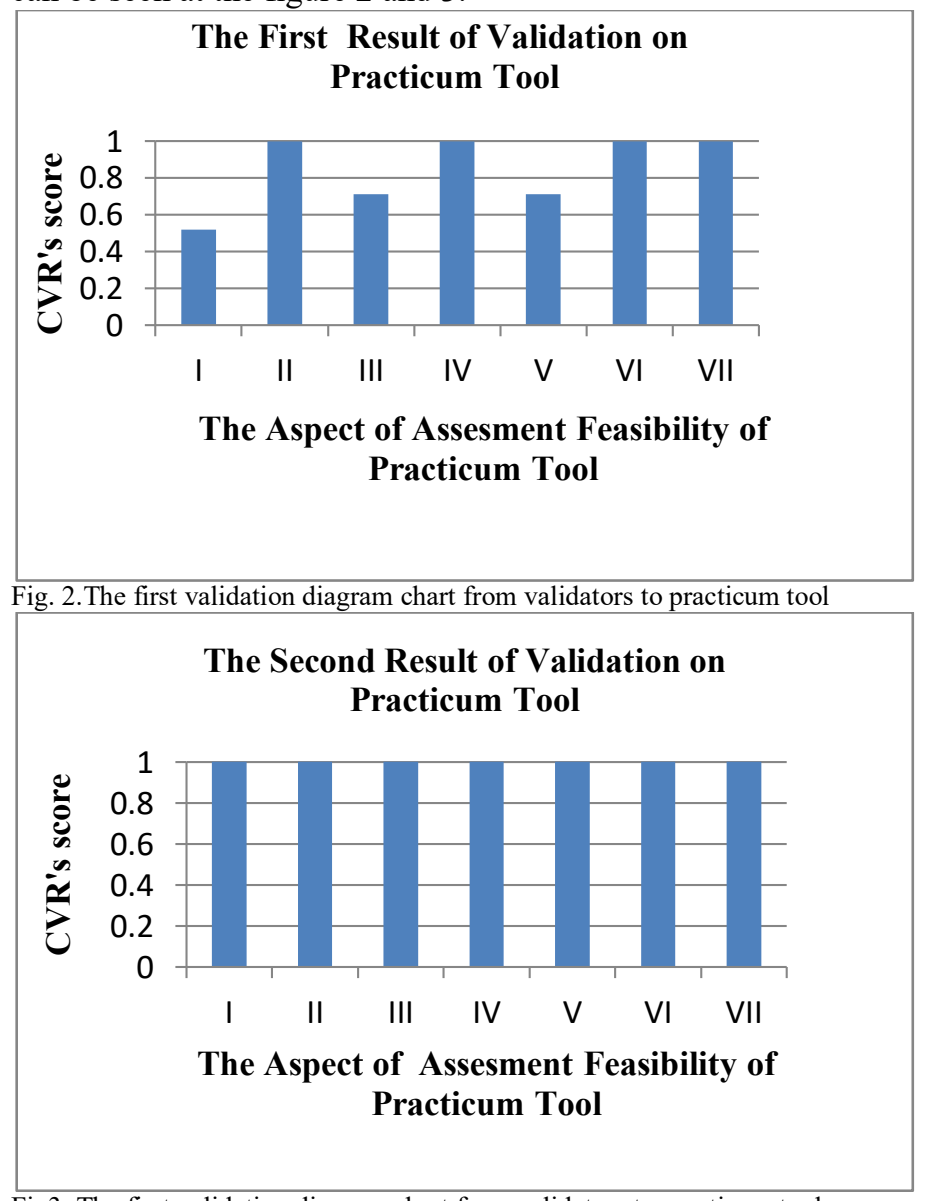

Fig3. The first validation diagram chart form validators to practicum tool

This is the picture of magnetic induction on solenoid after validating process showed at figure 4 .

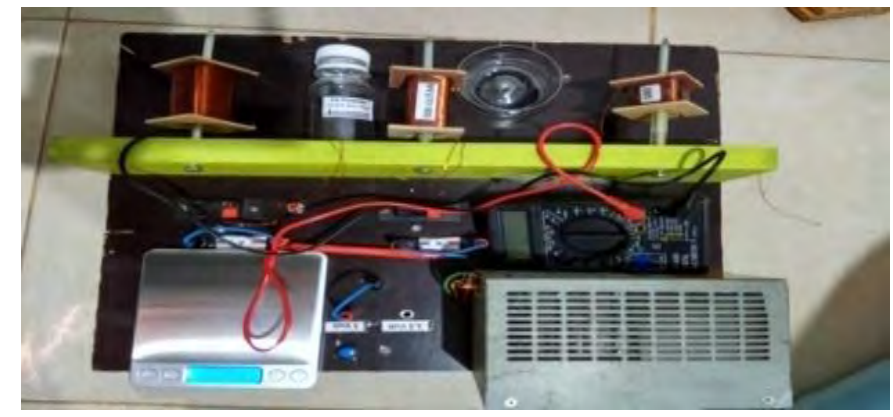

Fig. 4. Practicum Tool After Validating by the Validators

Students' work sheet consists of; (1) Cover. (2) Preface. (3) Table of contents. (4) Did you know. (5) Brief theory. (6) Practicum materials and tool. (7) Students practicum sheet consists of 3 practicum. Students' work sheet assessments have been validated by the seven physics teachers with 2 aspects; (1) Content. (2) Language.

Validation on students' work sheets is only done once because validators assume that the students' work sheet already good because it systematically prepared, the material is the essential problem, appropriate with the students' cognition, it have clear objective, foster students' curiosity, equipped with attractive picturesand the language use already adjust to Enhanced Indonesian Spelling System brief EYD. The assessment of students' work sheet is 1.00 with the criteria very relevant. The result on students' work sheet by the validators can be seen at the figure 5 .

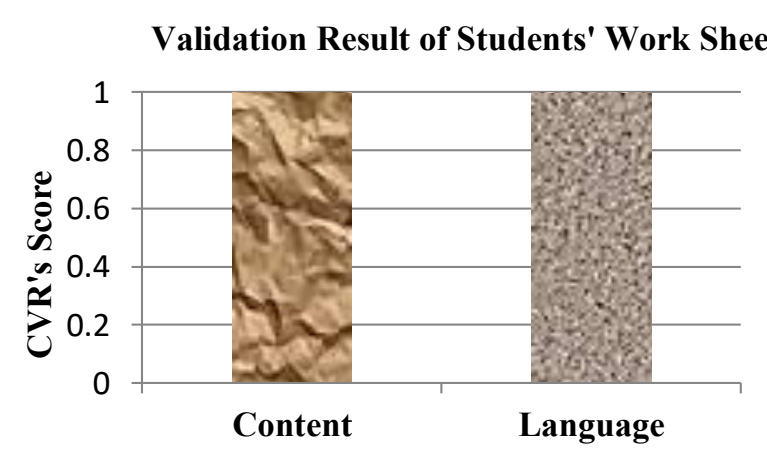

The Aspect of Assesment of Students' Work Sheet

Fig. 5. Validation diagram of students' work sheet

Magnetic induction practicum tools on solenoids were tested at school after being declared feasible by the validators. The testing stage is conducted to find out the students' response to the tools and effectiveness of the practicum tool. The testing was carried out with the participation of 30 students science class level XII 4 with the aspects of assessment consists of 8 aspects with yes and no choices. The result of testing got 0.88 with the criteria is very relevant. This figure is the comparison chart of aspects assessed in students' responses with CVR's score can be seen at figure 6 . 


\section{Students' responses to practicum tool}

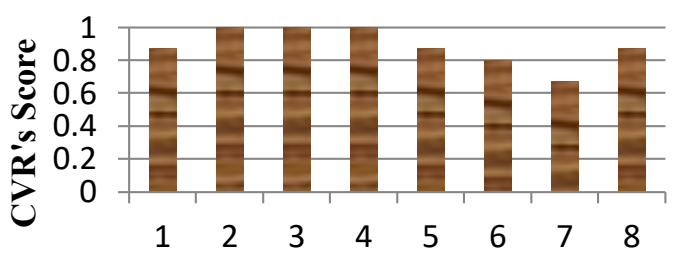

The Assesment Aspect of Students' Response

Fig. 6. Student Response Diagram of Practicum Tool

Essay test was given at the pre and post test in order to know about the students' conceptual understanding after they used the practicum tool. The data of pre and post test showed at table 2. The increasing of students' conceptual understanding from analysis result with $\mathrm{N}$-gain test got 0.45 for N-gain's score with the criteria at the middle. The increasing of students' conceptual understanding can be seen at figure 7 .

TABLE 2.Students' Pre and Post Test Score

\begin{tabular}{|c|c|c|}
\hline Components & Pre Test & Pos Test \\
\hline Number of Students & 30 & 30 \\
\hline Average & 40,2 & 67,2 \\
\hline Lowest Score & 28 & 33 \\
\hline Highest Score & 56 & 89 \\
\hline Completeness & 0 & 21 \\
\hline (\%) Completeness & $0 \%$ & $70 \%$ \\
\hline
\end{tabular}

\section{The Comperison of Pre Test and Post Test}

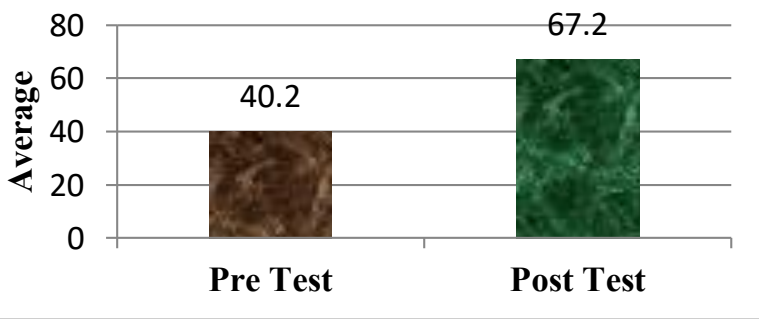

Fig. 7. The Concept of Conceptual Understanding

Based on the results of research, that using a magnetic induction practicum tool on solenoids can explore students'conceptual understanding. This is convenient with the previous researches. Mashudi (2013) in his journal stated that there is significant increase between increased of mastery optical concept and in using the eye model development media[11]. In the other research Prasetyarini (2013) stated that the use of science practicum media in measurement subject can increase the conceptual understanding of the students [12]. Hamdani (2012) stated that the use of practicum tool or media can increase the light conceptual understanding of the students [13].

Students' conceptual understanding can increase because the learning process used practicum tool according to Sriyono (1992:126) it would make the learning process become more interesting, construct the interest and attention of the students, making learning more concrete, making learning process become alive, interesting and fun [14]. Furthermore laboratory/practicum based learning according to Mashudi (2013) would give real experience from the concept that was still abstract become real and it would gave more learning experiences.

\section{The Theory of Practicum Tool in Terms of Physics}

Practicum tool is a device that can be absorbed by the eyes and earswith the aim of helping students to make the learning process more effectiveand efficient [15]. Practicum is not just using a tool but to show a principle, test the truth of the theoryand to strengthen understanding and trust[16].

Solenoid is a coil of wire whose diameter is very small compared to its length. If a solenoid is given a potential difference then on solenoid will appear magnetic induction or magnetic field. The magnitude of magnetic induction in the solenoid is used in the equation:

$$
B=\frac{\mu_{0} \cdot N . I}{l} \text { (1) } B=\frac{\mu_{0} \cdot \mu_{r} N . I}{l}
$$

$B \quad$ : magnetic induction(Tesla)

$\mu_{0} \quad$ : permeability of free space with the score $4 \pi \cdot 10^{-7}$ Wb/A.m

$\mu_{r} \quad$ : permeability of material (Wb/A.m)

$N \quad$ : the number of turns

I : the current $(A)$

$L \quad$ : length of coil $(\mathrm{m})$

Equation (1) for magnetic induction in the free space and the equation (2) for magnetic induction in the medium. From the equation above, then what influences the magnitude of magnetic induction is proportional to the current and number of turns and inversely proportional to the length of the solenoid.

The magnetic induction practicum tools on the solenoids which have been developed should be able to prove the theory that magnetic induction is proportional to the current and number of turns and inversely proportional to the length of the solenoid.

In the table below the practicum result and it has done to the magnetic induction practicum tool on solenoid.

TABLE 3.The Correlation Between the Number of Turnsand The Mass of Iron Powder was Attached.

\begin{tabular}{|c|c|c|c|c|c|}
\hline \multirow{2}{*}{ No } & \multirow{2}{*}{$\begin{array}{c}\text { Number of } \\
\text { Turns }\end{array}$} & \multicolumn{3}{|c|}{$\begin{array}{c}\text { Iron Powder Mass for } \mathbf{X}_{\mathbf{n}} \\
\text { Measurement (gr) }\end{array}$} & $\begin{array}{c}X \\
\text { (gr) }\end{array}$ \\
\cline { 3 - 5 } & & $\mathbf{X}_{\mathbf{1}}$ & $\mathbf{X}_{\mathbf{2}}$ & $\mathbf{X}_{\mathbf{3}}$ & \\
\hline 1 & 250 & 1,20 & 1,36 & 1,44 & 1,33 \\
\hline 2 & 500 & 1,62 & 1,50 & 1,81 & 1,64 \\
\hline 3 & 750 & 2,16 & 2,07 & 2,10 & 2,11 \\
\hline 4 & 1000 & 3,46 & 3,24 & 3,17 & 3,29 \\
\hline
\end{tabular}




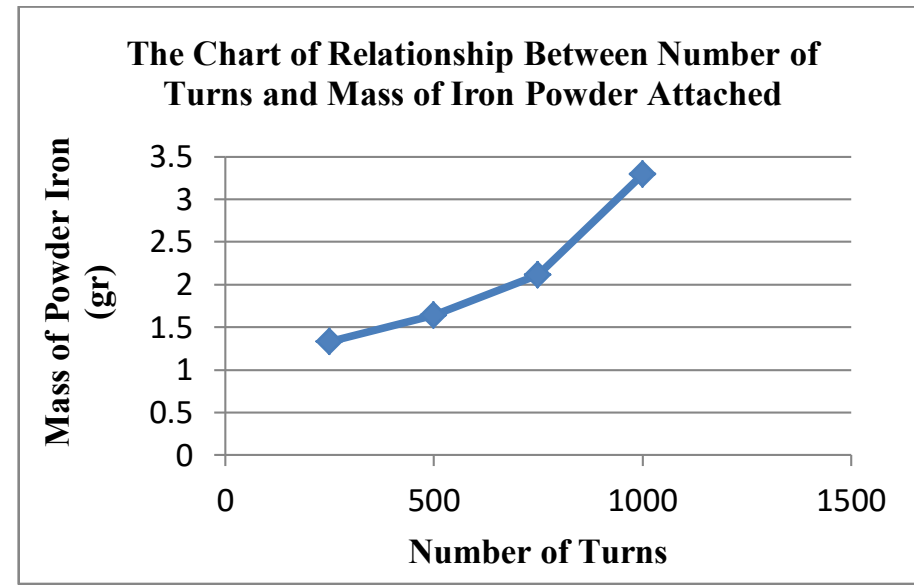

Fig. 8. The Chart of Relationship Between Number of Turns and Mass of Iron Powder Attached

TABLE 4. The Correlation Between the Current and The Mass of Iron Powder

\begin{tabular}{|c|c|c|c|c|c|}
\hline \multirow{2}{*}{ No } & \multirow{2}{*}{ The Current (A) } & \multicolumn{3}{|c|}{$\begin{array}{c}\text { Iron Powder Mass for } \mathbf{X}_{\mathbf{n}} \\
\text { Measurement (gr) }\end{array}$} & $\begin{array}{c}X \\
\text { (gr) }\end{array}$ \\
\cline { 3 - 5 } & & $\mathbf{X}_{\mathbf{1}}$ & $\mathbf{X}_{\mathbf{2}}$ & $\mathbf{X}_{\mathbf{3}}$ & \\
\hline 1 & 0,20 & 0,29 & 0,28 & 0,28 & 0,28 \\
\hline 2 & 0,21 & 0,29 & 0,30 & 0,30 & 0,30 \\
\hline 3 & 0,22 & 0,31 & 0,32 & 0,30 & 0,31 \\
\hline 4 & 0,23 & 0,32 & 0,32 & 0,31 & 0,32 \\
\hline 5 & 0,24 & 0,33 & 0,32 & 0,32 & 0,32 \\
\hline 6 & 0,25 & 0,33 & 0,33 & 0,32 & 0,33 \\
\hline 7 & 0,26 & 0,33 & 0,35 & 0,34 & 0,34 \\
\hline 8 & 0,27 & 0,35 & 0,34 & 0,34 & 0,34 \\
\hline 9 & 0,28 & 0,36 & 0,35 & 0,37 & 0,36 \\
\hline 10 & 0,30 & 0,37 & 0,36 & 0,37 & 0,37 \\
\hline 11 & 0,32 & 0,38 & 0,40 & 0,39 & 0,39 \\
\hline 12 & 0,34 & 0,40 & 0,39 & 0,41 & 0,40 \\
\hline 13 & 0,36 & 0,41 & 0,41 & 0,40 & 0,41 \\
\hline 14 & 0,38 & 0,44 & 0,41 & 0,43 & 0,43 \\
\hline 15 & 0,41 & 0,44 & 0,43 & 0,44 & 0,44 \\
\hline
\end{tabular}

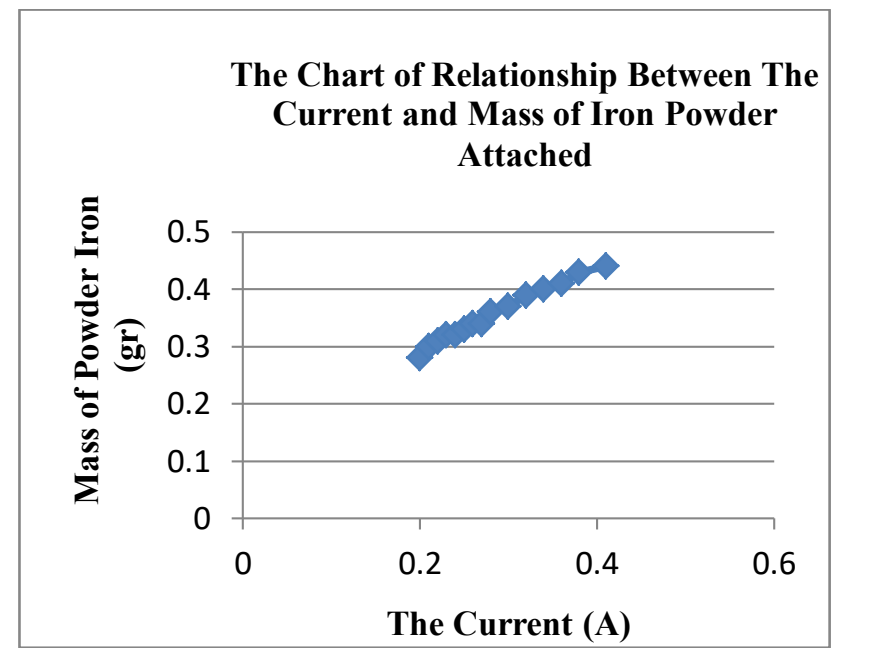

Fig. 9. The Chart of Relationship BetweenThe Current and Mass of Iron Powder Attached

Table 5. The Correlation Between the Length of Solenoid and the Mass of Iron Powder

\begin{tabular}{|c|c|c|c|c|c|}
\hline \multirow{2}{*}{ No } & $\begin{array}{c}\text { The Legth of } \\
\text { Solenoid (cm) }\end{array}$ & \multicolumn{3}{|c|}{$\begin{array}{c}\text { Iron Powder Mass for } \mathbf{X}_{\mathbf{n}} \\
\text { Measurement (gr) }\end{array}$} & $\begin{array}{c}X \\
\text { (gr) }\end{array}$ \\
\cline { 3 - 5 } & & $\mathbf{X}_{\mathbf{1}}$ & $\mathbf{X}_{\mathbf{2}}$ & $\mathbf{X}_{\mathbf{3}}$ & \\
\hline 1 & 1,2 & 3,09 & 3,14 & 3,05 & 3,09 \\
\hline 2 & 2,3 & 2,81 & 2,70 & 2,62 & 2,71 \\
\hline 3 & 3,5 & 2,49 & 2,50 & 2,43 & 2,47 \\
\hline 4 & 4,6 & 1,62 & 1,50 & 1,81 & 1,64 \\
\hline
\end{tabular}

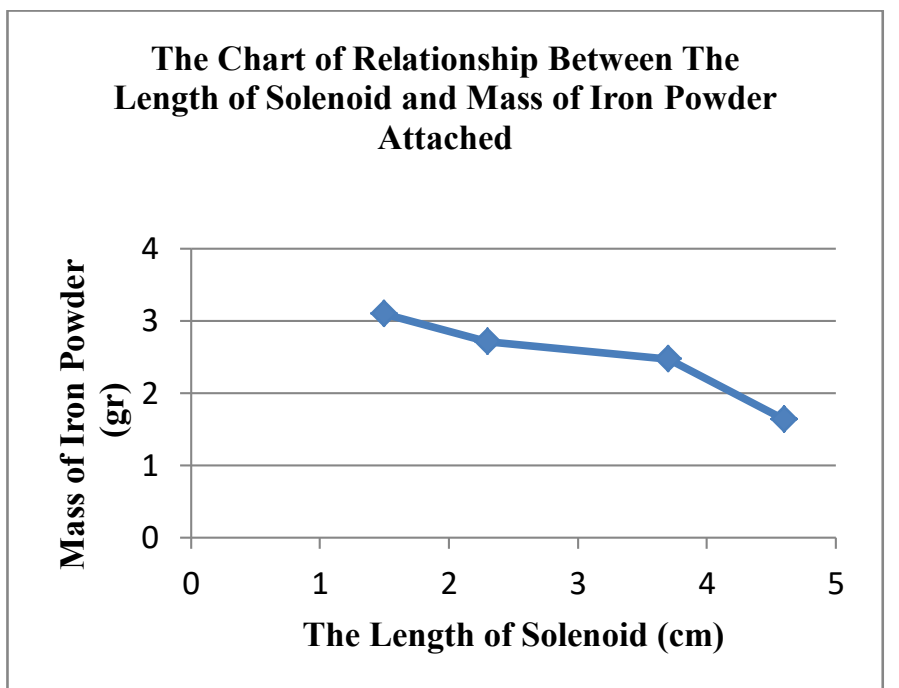

Fig. 10. The Chart of Relationship Between The Length of Solenoid and Mass of Iron Powder Attached

The mass of iron powder attached indicates the magnitude of magnetic induction in the solenoid. The more iron powder sticks, means the greater the magnetic induction. Based on the result of practicum result in the table 3,4 and 5 so the magnitude of magnetic induction is proportional to the number 
of turns and the current and inversely proportional to the length of the solenoid.

\section{CONCLUSION}

Magnetic induction practicum tool on solenoids accompanied by student worksheets is a practicum tool used by the teacher in the learning process to clarify concepts and phenomena and to prove the theory of magnetic fields in the solenoid. Based on the results of the research showed the level of feasibility for practical equipment and students' worksheets got 1.00 , so it can be concluded that the magnetic induction practicum tool on the solenoid and the students' worksheet were in very relevant criteria. Students' responses got 0.88 were in very relevant criteria. Gain test result showed that the increasing students' conceptual understanding after the students have done the learning process with used the magnetic induction practicum tool on solenoid got 0.45 and the completeness got $70 \%$ in each average criteria.

\section{REFERENCES}

[1] Betha, N. 2004. Sistem Pembelajaran KBK Terhadap Motivasi para Peserta Didik pada Bidang Fisika. Artikel.us/art05-57.html-16k.9 November 2004.

[2] Hartati, B. 2010. Pengembangan Media Gaya Gesek untuk Meningkatkan Keterampilan Berpikir Kritis Siswa SMA. Jurnal Pendidikan Fisika Indonesia.128-132.

[3] Gunter, R. D. 2010. Multimedia Learning: Are Still Masking the Questions? Journal of Educational Multimedia and Hypermedia, 19 (1): $103-120$.

[4] Burhan. 2006. Pembelajaran IPA.Jakarta :RinekaCipta

[5] Deacon, C. 2011. Student Perceptions of the Value of Physics Laboratories. International Journal of Science Education. Vol. 33 (7): 943-977.

[6] Borrmann, T. 2008. Laboratory Education in New Zealand.Eurasia Journal of Mathematics, Science and Technology Education. Vol.4 (4): 327-355.

[7] Borg, W.R. \& Gall, M.D. 1989. Educational Research : An Introduction, Fifth Edition. New York: Longman.

[8] Branch, R. B. 2009. Instructional Design: The ADDIE Approach. New York: Spinger.

[9] Arikunto, S., Suhardjono dan Supardi. 2015. Penelitian Tindakan Kelas. Jakarta: Bumi Aksara.

[10] Lawshe, C. H. 1975. A Quantitative Approach to Content Validity.Personnel Psychology. 28(4), 563-575.

[11] Mashudi, A. 2013. Pengembangan Media Model Mata Manusia untuk Meningkatkan Penguasaan Konsep Optik.JPII Journal 2(1): 93-101

[12] Prasetyarini, A., Fatmaryanti, S.D. dan Akhdinirwanto, R.W. 2013. Pemanfaaatan Media Sederhana IPA Untuk Peningkatan Pemahaman Konsep Fisika Pada Siswa SMP Negeri 1 Bulu pesantren Kebumen Tahun Pelajaran 2012/2013.Radiasi2 (1): 7-10.

[13] Hamdani , D., Eva, K. Dan Indra, S. Pengaruh Model Pembelajaran Generatif dengan Mneggunakan Media terhadap pemahaman Konsep Cahaya Kelas VIII di SMP Negeri 7 Kota Bengkulu. Jurnal Exacta. 10(1): 79-88.

[14] Sriyono, dkk. 1992. Teknik Belajar Mengajar dalam CBS. Jakarta: Rineka Cipta.

[15] Lina, P,. 2012. Efektivitas Metode Praktikum dengan Alat Peraga Periskop Sederhana Pelajaran IPA terhadap Kreativitas Siswa Kelas V SD Kanisius Cungkup Kecamatan Sidorejo Kota Salatiga Semester II Tahun Pelajaran 2011/2012. Skripsi, Malang: FMIPA.

[16] Sujana, N. 2008. Penelitian Proses Belajar Mengajar. Bandung: PT. Remaja Rosda Karya.
[17] Theraja, B. L and Theraja, A. K. 1989. Electrical Technology. New Delhi. Nirja Construction \& Development Co. (P) Ltd. 